\title{
Pembelajaran Kontekstual di Masa Pandemi untuk Mengembangkan Kerohanian Anak
}

\author{
Mitra Binariang Lase ${ }^{1 *}$, Benteng Martua Mahuraja Purba ${ }^{2}$, Desetina \\ Harefa $^{3}$, Efvi Noyita ${ }^{4}$, Hendrik Bernadus Tetelepta ${ }^{5}$ \\ 1,2,3,4, Prodi PAK, STT Real Batam \\ ${ }^{5}$ Prodi Teologi, STT Real Batam \\ mitralase97@gmail.com
}

\begin{abstract}
The spiritual dimension is the goal of the national education section. While the teacher himself as a professional educator. However, during the pandemic, it is currently ready to use learning patterns that must be adapted to the circumstances. This literature research and writing method aims to discuss spiritual meaning and provide a learning model in order to develop children's spirituality during a pandemic. The contextual learning model should be cheated by educators, because this learning model focuses more on the uniqueness of students.
\end{abstract}

Keywords: Child Spirituality, Contextual Learning, Pandemic period.

\begin{abstract}
Abstrak
Dimensi kerohanian menjadi tujuan dari bagian pendidikan nasional. Sedangkan guru sendiri dimengerti sebagai pendidik yang professional. Akan tetapi di masa pandemi saat ini memaksa keadaan khususnya pada pola pembelajaran yang harus disesuaikan dengan keadaan. Tulisan dan metode riset kepustakaan ini mempunyai tujuan untuk membahas makna kerohanian dan memberikan model pembelajaran guna untuk mengembangkan kerohanian anak di masa pandemi. Model pembelajaran kontekstual patut dipertimbangkan oleh para pendidik, sebab model pembelajaran ini lebih berfokus pada keunikan peserta didik.

Kata Kunci: Kerohanian Anak, Pembelajaran Kontekstual, Masa pandemi
\end{abstract}




\section{PENDAHULUAN}

Sikap yang harus ada dalam pribadi anak untuk menjadi baik adalah mempunyai perilaku/sikap dan nilai moral yang sesuai dengan etika masyarakat, keluarga dan agama. Upaya dalam membangun sikap seperti ini membutuhkan waktu dan proses yang baik. Mengajarkan sikap dan nilai moral kepada anak sedini sangat penting hal ini telah disepakati oleh para ahli.

Selanjutnya, dimasa perkembangan anak sangat dibutuhkan untuk mengajarkan tentang sikap dan nilai moral yang baik sehingga sesuai dengan kebutuhan dimasa usianya dan juga memberi dampak pada pembentukkan serta penguatan karakter anak di masa dewasanya kelak. ${ }^{1}$ Menurut Havighurst, bahwa setiap tahap pada perkembangan usia anak memiliki potensi untuk mengembangkan kemampuan hati Nurani dalam membedakan yang baik dan salah, mulai dari hal yang sederhana. ${ }^{2}$ Contohnya memberi salam kepada semua orang, mengucapkan terimakasih, meminta maaf, meminta izin serta tidak berbuat curang dan lain sebagainya. Dalam hal ini orang tua memiliki peran yang sangat penting, akan tetapi pengajaran di sekolah tidak kalah pentingnya dengan orangtua di rumah. Apalagi pada tahap pendidikan dasar 5-12 tahun, pengajaran yang disampaikan oleh guru, anak-anak sangat terbuka untuk menerimanya.

Di masa pendidikan awal, guru mempunyai peran besar dalam membangun sikap dan nilai moral pada anak, Itu sebabnya, sikap dan perilaku karakter seorang guru/pengajar pada umunya menyenangkan dan ramah, sehingga peserta didik bisa lebih mudah dalam menyerap kebaikan moral dan sikap melalui keteladan mereka. ${ }^{3}$ Sarana pembelajaran yang terbaik bagi anak memahami moralitas dalam kehidupan sehari-hari adalah menjadi teladan yang baik dan benar. Apa yang dimaksud dengan moralitas para guru biasanya menjelaskan materi dengan cara mempraktekkanya di depan semua siswa.

Akan tetapi, keteladan yang diberikan oleh guru lewat tatap muka dan interaksi, terhalang sejak merebaknya pandemi covid-19. Kebiasaan belajar dalam kelas yang berlangsung sekitar 8 jam perhari berubah dengan mengikuti kebijakan pemerintah yang mengharuskan semua kegiatan

\footnotetext{
${ }^{1}$ Robert W Carpps, Perkembangan Keperibadian \& Keagamaan (Yogyakarta: Kanisius, 1994). 11

${ }^{2}$ Elisabeth Hurlock, Psikologi Perkembangan: Suatu Pendekatan Sepanjang Rentang Kehidupan, Ridwan Max. (Jakarta: Erlangga, 1980). 10

${ }^{3}$ Otib Satibi Hidayat, Metode Pengembangan Moral Dan Nilai-Nilai Agama, Nurul Hikm. (Banten: Universitas Terbuka, 2015).xi
} 
dilakukan di rumah masing-masing termasuk proses pembelajaran. ${ }^{4}$ Keputusan pemerintah tersebut diikuti dengan banyak himbaun termasuk penerapan PSBB (Pembatasan Sosial Berskala Besar) melakukan social distaching, dan berbagai kebijakan-kebijakan lainnya, namun hal ini berguna untuk memutuskan penyebaran covid-19.

Kementerian pendidikan dan Kebudayaan memutuskan supaya semua Lembaga pendidikan mulai dari Pendidikan Anak Usia Dini sampai pada Perguruan Tinggi mengubah pembejalaran tatap muka menjadi pembelajaran jarak jauh (study from home). ${ }^{5}$ Pembelajaran yang duluya dilakukan lewat tatap muka dialihkan pada pembelajaran jaringan. Pastinya ada konsekuensi pada perubahan model pembelajaran dari konvensional menuju Cyber pedagogy. Tidak hanya sekedar pada ketersediaan fasilitas yang diperlukan saat belajar akan tetapi bagaimana mempersiapkan dan mengajarkan setiap materi ajar dari tatap muka menjadi daring tanpa mengurangi capaian pembelajaran yang sudah ditetapkan.

UNESCO menyebutkan bahwa di 59 negara dunia di dalamnya termasuk Indonesia terkait system pendidikan selama pandemi mengalami kesenjangan pengajar dalam menggunakan teknologi informasi dan komunikasi (TIK). ${ }^{6}$ Sebagai tenaga pendidik ada beberapa hal yang perlu untuk segera di atasi yang pertama mempersiapkan materi untuk dibagikan kepada peserta didik secara daring, kedua penguasaan teknologi sebagai penunjang pembelajaran. Jika hal tersebut gagal untuk dipersiapkan maka akan berdampak pada setiap proses pembelajaran.

Peserta didik yang mengikuti pembelajaran daring terdapat dalam jumlah yang banyak, namun beberapa respon dari para pendidik mengaku bahwa tidak semua siswa berpartisipasi dalam mengikuti pembelajaran daring tersebut. Penyebabnya bermacam-macam, mulai keterbatasan orangtua dalam penyediaan fasilitas sebagai penunjang proses belajar hingga ketidaksiapan guru dalam penggunaan teknologi. ${ }^{7}$ Ujungnya persoalan yang terjadi di masa pandemi pada proses pembelajaran mengalami dampak pada suatu pencapaian tujuan pembelajaran pada semua dimensi, salah satunya dimensi kerohanian.

\footnotetext{
${ }^{4}$ Zubi Mahrofi, "Indef: Himbauan Pemerintah Harus Jadi Perhatian Pengusaha," ANTARANEWS.COM.

${ }^{5}$ Pengelola Web Kemendikdub, "Kemendikbud Terbitkan Pedoman Penyelenggaraan Belajar Dari Rumah," Kemdikbud.Go.Id.

${ }^{7}$ Andri Anugrahana, Hambatan, Solusi dan Harapan: Pembelajaran Daring Selama Masa Pandemi Covid-19 Oleh Guru Sekolah Dasar, Jurnal Pendidikan dan Kebudayaan, Vol. 10 No. 3, September 2020. 286
} 
Sebagai pendidik harus benar-benar profesional dalam melaksanakan model pembelajaran yang memungkinkan untuk mencapai tujuan pembelajaran di masa pandemi, termasuk dalam mempertimbangkan kebutuhan anak sesuai dengan masa pertumbuhannya sebagai dasar pembentukkan kerohaniannya pribadi di masa-masa yang akan datang, oleh sebab itu seorang pengajar ditantang untuk memakai model pembelajaran yang sesuai dengan keadaan dan situasi saat ini. Sebagai model pembelajaran yang dibahas dalam penulisan adalah model pembelajaran kontekstual.

\section{METODE}

Pendekatan yang digunakan dalam penulisan ini adalah riset kepustakaan. Riset kepustakaan ini digunakan dalam rangka untuk mengumpulkan informasi serta data dan bantuan berbagai macam sumber baca dari perpustakaan. Oleh sebab itu, riset kepustakaan membatasi kegiatannya hanya pada sumber-sumber pustaka saja tanpa adanya survei lapangan.

\section{HASIL DAN PEMBAHASAN \\ Kerohanian Kristiani}

Dalam kamus besar bahasa Indonesia (KBBI) kerohanian merupakan sifat-sifat rohani yang berhubungan dengan roh. ${ }^{8}$ Sementara Cahya Dicky Pratama menyebutkan bahwa kerohanian ada beberapa nilai-nilai yang terkandung di dalamnya yakni: Nilai kebenaran, nilai keindahan, nilai moral dan nilai keagamaan. ${ }^{9}$ Kerohanian dipahami secara utuh. Manusia ada karena nafas Allah, pandangan ini dibangun dari kebenaran (Kej. 2:7) yang menghidupkan, Roh Allah (Kej. 1:2) merupakan pribadi yang menciptakan manusia. Heuken berpendapat bahwa kerohanian manusia dibangun atas dasar kebenaran bahwa manusia ialah makhluk rohani. ${ }^{10}$ Artinya manusia adalah pribadi yang utuh (Rohani dan Jasmani), diciptakan menurut gambar dan rupa Allah dan manusia itu dipanggil untuk mewujudkan kehadiran Allah melalui hubungan dengan Sang Sumber kehidupan. Namun manusia itu sendiri telah gagal untuk mencapai tujuan Allah dalam hidupnya karena dosa sehingga berdampak pada rusaknya relasi manusia dengan Allah, sesama dan semesta. Sangat jelas bahwa manusia tidak bisa memulihkan

\footnotetext{
${ }^{8}$ Departemen Pendidikan Nasional, Kamus Besar Bahasa Indonesia Pusat Bahasa (Jakarta: Gramedia Pustaka Utama, 2008). 1179

${ }^{9}$ Cahya Dicky Pratama, "Nilai Kerohanian Dalam Kehidupan Sosial," Kompas.Com, last modified 2020, https://www.kompas.com/skola/read/2020/10/19/141549369/nilai-kerohanian-dalamkehidupan-sosial?page $=$ all.

${ }^{10}$ Adolf Heuken, Spiritualitas Kristiani-Pemekaran Hidup Rohani Selama Dua Puluh Abad (Yogyakarta: Yayasan Cipta Loka Caraka, 2002). 7
} 
dirinya sendiri. Oleh karena kemurahan Tuhan Ia memulihkan manusia berdosa menurut gambar-Nya. Berangkat dari kebenaran ini, maka dalam penataan kerohanian manusia menekankan mulai dari tindakan Allah (Ef.2:810), dengan maksud memulihkan hubungan manusia dengan Allah dan hubungan sesama dan semesta. Sebab itu kerohanian merupakan cara mewujudkan kehadiran dirinya dalam pribadi sebagai seorang beriman yang terus berusaha merancang serta menjalankan hidup sesuai dengan kehendak Allah.

Perjalanan kerohanian kekristenan merupakan sebuah komitmen yang terus-menerus bertumbuh seumur hidup yang menuju pada keutuhan di dalam Kristus yang adalah kepala (Ef.4:15), hingga manusia mencapai kedewasaan penuh yang sesuai dengan kepenuhan Kristus. Allah hadir dan aktif dalam setiap kehidupan orang percaya. Jika dikaitkan dalam kehidupan anak pada tahap perkembangnya, dimana pada masa anak-anak sangat lebih mudah untuk menerima ajaran dan keteladan. Yesus yang dibesarkan dibawah kerohanian Yahudi kemungkinan besar kedua orangtua-Nya mewarisi tradisi kerohanian Israel.

Tradisi dalam perjalanan kerohanian Israel bukan hanya bermula dari konsep melainkan bersumber dari pengalaman keseharian dalam menjalankan ibadah serta ketaatan kepada pada perintah Tuhan (Ulangan 6: 4-9). Paling tidak ada tiga hal dasar dalam kerohanian. Yang pertama, lapisan kerohanian anak berawal dari kehidupan atau pengalaman dalam keluarga bersama dengan orangtua dan orang-orang yang tinggal di dalam rumah. Sebagai orangtua selaku pendidik dalam keluarga harus memberikan keteladan yang benar maka pastinya anak akan menirunya. James Garder mengatakan bahwa dari orangtualah anak mewarisi nilai-nilai kerohanian dan konsep dasar berkenaan dengan hidup. ${ }^{11}$ Orangtua harus terus memastikan bahwa dirinya sudah melakukan hal yang baik dan benar. Kedua, kerohanian anak berlandaskan pada pengalaman, namun formasi itupun harus dilakukan dengan sadar/sengaja. Dalam posisi pendidikan saat ini, kebenaran ini dilakukan lewat kurikulum yang memiliki tujuan untuk membangun pengalaman kerohanian tentang Allah, yang berwujud dengan kebaikan antara sesama dan lingkungan sekitar anak. Dan yang ketiga, bahwa formasi kerohanian anak merupakan sebuah proses. Seperti bangsa Israel yang selama 430 tahun hidup dalam bayang-bayang kerohanian Mesir, wajar saja jika Israel dalam perjalanan menuju Kanaan penuh dengan gejolak karena telah mencerminkan romantisme budaya Mesir. Israel jelas tidak mudah

${ }^{11}$ Mardiharto, "Pola Asuh Pendidikan Kerohanian Anak," PASCA : Jurnal Teologi dan Pendidikan Agama Kristen 15, no. 1 (2019). 23-27 
percaya kepada Tuhan sebab kepercayaan orang Mesir berpusat pada dewadewa. Oleh sebab itu mengubah suatu kebiasaan lama yang sudah tertanam bukanlah suatu hal yang mudah. ${ }^{12}$ Dalam hal ini menjelaskan bahwa untuk menjadi baik membutuhkan kekosistenan dan waktu keteladan dari orangtua/guru.

\section{Model Pembelajaran Kontekstual dan Peran Pendidik}

Pembelajaran kontekstual sebagai sebuah model yang bersesuaian dengan karakteristik pengembangan kerohanian anak. Lewat model pembelajaran ini, pembelajaran luar jaringan maupun dalam jaringan bukan hanya memikat, tetapi juga diupayakan sesuai dengan kebutuhan anak atau konteksnya di masa pandemi. Dapat dipahami bahwa makna konteks adalah sebagai benda atau kejadian nyata, model dari konsep yang akan dipelajari sesuatu yang dibayangkan oleh peserta didik. ${ }^{13}$ Model pembelajaran kontekstual sendiri dapat membantu siswa untuk mengaitkan setiap teori yang ia dapat dengan situasi dunia nyatanya, serta mendorong anak untuk menerapkan hubungan antara pengetahuan yang ia dapat dengan kehidupan sehari-hari sebagai wujud kerohaniannya.

Dalam penerapannya, pembelajaran kontekstual memiliki empat prinsip pembelajaran yang implementasinya dapat disesuaikan dengan kebutuhan pengembangan kerohanian anak. Yang pertama, konstruktif. prinsip ini dapat menolong para pendidik untuk mendapatkan makna dalam proses pembelajaran dengan cara menautkan apa yang sudah dipelajari dan apa yang akan dipraktikan. Tugas pendidik ialah mendorong anak untuk menemukan apa yang menjadi makna pembelajaran kerohanian melalui kegiatan yang rutin dilakukan. Misalnya materi pelajaran yang bertemakan tentang kasih yang dapat di wujudkan lewat beribadah kepada Tuhan dan mengasihi sesama dapat dipraktekkan dalam bentuk perbuatan baik. Sebagai pendidik harus benar-benar memastikan bahwa anak didik bukan hanya melaksanakan tugas namun harus memahami alasan-alasan dan mengapa pembelajaran itu dilakukan. Otomatis anak didik akan terbiasa membangun makna konstruktif dari semua pengalaman yang ia peroleh. Pendidik harus memberikan kebebasan kepada anak didik untuk mengekpresikan pengalaman-pengalamannya, baik kepada Tuhan maupun kepada sesama manusia.

\footnotetext{
${ }^{12}$ Andrew Hill and John Walton, Survei Perjanjian Lama (Malang: Gandum Mas, 1996).

${ }^{13}$ Rusman, Model-Model Pembelajaran-Mengembangkan Profesional Guru (Jakarta: Raja Grafindo Persada, 2016). 188
} 
Kedua, adalah menemukan sendiri. Sebagai pendidik harus mengijinkan anak didik untuk bisa menceritakan kembali pengalaman kerohanian yang ia dapatkan pada saat melakukan tugas. Pendidik bisa mengajukan pertanyaan kepada peserta didik atau memberikan kesempatan untuk mengekspresikan bentuk ucapan syukur baik dalam bentuk pujian maupun doa serta puisi. Fokusnya disini ialah melatih peserta didik untuk memiliki keberanian serta melatih anak untuk mempunyai kedalam pengalaman kerohaniannya.

Ketiga, Bertanya. Dalam hal ini pendidik menggunakan kesempatan yang ada untuk bertanya kepada peserta didik guna menggali infomasi sebanyak mungkin. Pendidik juga harus mengikutkan pertanyaan-pertanyaan di setiap tugas yang diberikan kepada peserta didik contohnya apa yang kamu pelajari tentang orang lain dan Tuhan? serta berbagai ragam pertanyaan yang lainnya. Hal ini berguna untuk melatih peserta didik untuk mengaitkan kesehariannya dengan kenyaat yang lebih besar dari dirinya; sehingga ada usaha untuk menemukan implementasi yang baik berupa Tindakan-tindakan positif bagi orang lain. Dengan begitu peserta didik belajar mempercayai bahwa ada Tuhan yang berdaulat dalam hidupnya.

Keempat, pendidik merupakan model terbaik bagi seorang anak atau peserta didik. Apa yang dilakukan oleh seorang pendidik tanpa disadari menjadi sebuah pola bagi anak untuk meneladani. Pendidik harus berupaya untuk memberikan keteladan bagi anak baik lewat pribadi pendidik sendiri, cerita, video atau dengan praktik langsung, dengan hal itu anak bisa langsung mengerti dan memahami capaian pembelajaran kerohanian yang diharapkan. Sebagai pendidik bisa memberikan contoh dengan kata-kata yang baik dan juga menjelaskan bagaimana melakukan perbuatan yang baik bagi orang lain. Yang paling terpenting adalah bukan soal apa yang anak bisa lakukan melainkan memberi kesempatan secara sistematis dan terarah kepada anak berproses mengalami kerohaniannya.

Adapun pengembangan kerohanian anak lewat pendidikan kristiani dilaksanakan di konteks gereja, sekolah dan rumah. ketiganya ini memiliki model yang berbeda-beda akan tetapi dalam penerapan dasar pendidikannya sama-sama berbasis Firman Tuhan atau berlandaskan pada kebenaran di dalam Alkitab melalui pengenalan akan Allah dan tuntunan dari Roh kudus.

\section{KESIMPULAN}

Dari pembahasan di atas, penulis menyimpulkan bahwa pendidikan kristiani sangatlah penting untuk membentuk kerohanian generasi milenial saat ini. Kerohanian merupakan sebuah anugerah dari Allah dan lewat 
pendidikan diarahkan kepada semua manusia khususnya kepada generasigenerasi milenial untuk merenungkan serta bertanggung jawab dihadapan Tuhan setiap aspek hidupnya. Dengan kata lain, kerohanian membangun hubungan dengan Allah yang mampu masuk dalam kehidupan manusia dari berbagai aspek.

Secara singkat, penelitian ini diharapkan dapat diterapkan dan juga meningkatkan kerohanian anak di masa pandemi melalui pendidikan kristiani pada pembelajaran kontekstual. Beberapa prinsip yang dipaparkan oleh penulis, pembelajaran kontekstual dapat dipertimbangakn sebagai model pembelajaran yang efektif untuk melakukan modeling, pelatihan, pendampingan, serta penilaian atas tindakan moral anak dengan berbasis pada pengalaman-pengalaman baik itu secara pribadi maupun dengan komunitas. Oleh sebab itu, formasi kerohanian anak di masa pandemi saat ini, merupakan sesuatu yang sangat mungkin untuk dilakukan melalui model pembelajaran kontekstual.

\section{KEPUSTAKAAN}

Carpps, Robert W. Perkembangan Keperibadian \& Keagamaan. Yogyakarta: Kanisius, 1994.

Heuken, Adolf. Spiritualitas Kristiani- Pemekaran Hidup Rohani Selama Dua Puluh Abad. Yogyakarta: Yayasan Cipta Loka Caraka, 2002.

Hidayat, Otib Satibi. Metode Pengembangan Moral Dan Nilai-Nilai Agama. Nurul Hikm. Banten: Universitas Terbuka, 2015.

Hill, Andrew, and John Walton. Survei Perjanjian Lama. Malang: Gandum Mas, 1996.

Hurlock, Elisabeth. Psikologi Perkembangan: Suatu Pendekatan Sepanjang Rentang Kehidupan. Ridwan Max. Jakarta: Erlangga, 1980.

Kemendikdub, Pengelola Web. "Kemendikbud Terbitkan Pedoman Penyelenggaraan Belajar Dari Rumah." Kemdikbud.Go.Id.

Mahrofi, Zubi. "Indef: Himbauan Pemerintah Harus Jadi Perhatian Pengusaha." ANTARANEWS.COM.

Mardiharto. "Pola Asuh Pendidikan Kerohanian Anak." PASCA : Jurnal Teologi dan Pendidikan Agama Kristen 15, no. 1 (2019).

Nasional, Departemen Pendidikan. Kamus Besar Bahasa Indonesia Pusat Bahasa. Jakarta: Gramedia Pustaka Utama, 2008.

Pratama, Cahya Dicky. "Nilai Kerohanian Dalam Kehidupan Sosial." Kompas.Com. Last modified 2020. https://www.kompas.com/skola/read/2020/10/19/141549369/nilai -kerohanian-dalam-kehidupan-sosial?page=all. 
Rusman. Model-Model Pembelajaran-Mengembangkan Profesional Guru. Jakarta: Raja Grafindo Persada, 2016. 